\title{
Finna - käyttäjät ja trendit 2016
}

\author{
Jyrki Messo \& Riitta Peltonen
}

\begin{abstract}
Finna toteutti vuoden 2016 lopulla ison käyttäjäkyselyn osana Finnan trendiraporttia. Finnassa on alusta lähtien ollut periaate käyttäjäkeskeisestä kehittämisestä ja loppukäyttäjien kuuntelusta. Nykyaikana sähköiset menetelmät mahdollistavat varsin laajankin käyttäjäpalautteen keruun.
\end{abstract}

\section{Finna pähkinänkuoressa}

Finna on paitsi hakukone, joka tarjoaa yli 13 miljoonan kohteen aineistotiedot yli 200 suomalaisesta kirjastosta, arkistosta ja museosta, niin myös asiakasliittymä yhä useamman kirjaston aineistoihin ja palveluihin. Finnan kautta käyttäjä saa aineistojen saatavuustiedot eri toimipisteissä, sen avulla voi varata aineistoja, uusia lainoja, maksaa lainasakkoja, käyttää sähköisiä materiaaleja jne. Keskeinen syy sille, että Finna pystyy tarjoamaan hyvinkin monen tyyppistä aineistoa yhden hakuliittymän kautta, on eri aloilla käytössä olevien standardoitujen tietoformaattien hyödyntäminen. Ilman kirjastoalan MARC 21:stä, museoiden LIDO:a ja arkistojen EAD-standardia Finnaan olisi pitänyt luoda niin hirvittävä määrä organisaatiokohtaisia erikseen ylläpidettäviä järjestelyjä aineiston haravoimiseksi yhteiseen indeksiin, ettei Finnaa nykymuodossaan voisi olla olemassa.

Finna tarjoaa aineistoihin erittäin monipuoliset hakumahdollisuudet. Hakua voidaan rajata esim. aineistotyypin ja käyttöoikeuksien, organisaation, sijainnin, kielen tai vaikkapa ajanjakson perusteella. Rekisteröitynyt käyttäjä voi tallentaa tekemiään hakuja ja lisäksi hakutuloksista löytyviä mielenkiintoisia kohteita voidaan siirtää omille suosikkilistoille. Näitä voidaan haluttaessa jakaa myös ulkopuolisille linkkeinä tai vaikkapa blogissa näytettävänä RSS-syötteenä. Hiljattain Finnaan toteutettiin Finna Street -palvelu, jonka avulla on mahdollista löytää historiallisia kuvia juuri sieltä, missä käyttäjä sattuu olemaan.
Kansallisessa Finna.fi-näkymässä Finna-käyttäjätiliin on mahdollista liittää useita kirjastokortteja eri kirjastoista, jolloin saman näkymän alta voidaan haluttaessa hallinnoida vaikkapa koko perheen lainat useasta eri kirjastosta.

\section{Finna osana kirjastojen verkkopalveluita}

Ajatus Finnasta syntyi Eurooppalainen digitaalinen kirjasto -hankkeen myötä 2005-2008 ja vuonna 2008 käynnistyi OKM:n rahoittama suomalaisten kirjastojen, arkistojen ja museoiden yhteinen Kansallinen digitaalinen kirjasto -hanke, jossa ensin vuodesta 2010 alkaen kokeiltiin kaupallista tuotetta palvelujen tuottamiseksi ja vuonna 2012 päätettiin, että Finnaa kehitetään avoimen lähdekoodin hankkeena, kun kävi ilmeiseksi, ettei valitulla kaupallisella tuotteella voida toteuttaa vaadittuja ominaisuuksia. Finnan pohjalla on Villanovan yliopistossa kehitetty VuFind, jota kehitetään erityisesti suomalaisiin tarpeisiin vastaavaksi Kansalliskirjaston kirjastoverkkopalveluissa. Joka kolmas viikko Finnan ohjelmistosta julkaistaan parannuksia ja uusia ominaisuuksia tuova päivitetty versio.

Kirjastoille Finna on ennen kaikkea asiakasliittymä siinä suuressa kokonaisuudessa, missä Melindassa hoidetaan aineistojen kuvailua ja erilaisissa kirjastojärjestelmissä, kuten Voyager ja Aurora, kirjaston omia kokoelmia ja palveluja. Finna tarjoaa siihen liittyneille organisaatioille mahdollisuuden tuoda aineistonsa Finnan yhteiseen indeksiin ja sen lisäksi organisaatio voi luoda 
Finnan avulla omille käyttäjille räätälöidyn verkkokirjaston eli nk. Finna-näkymän organisaation omiin aineistoihin ja palveluihin. Kirjastot voivat tarjota asiakkailleen pääsyn valtavaan määrään sähköisessä muodossa olevia aineistoja Primo Central Index -haun avulla ja Finna toimii myös väylänä korkeakoulujen opiskelijoilleen ja henkilökunnalleen lisensoimiin aineistoihin. Tällä hetkellä kansallisen Finna.fi-näkymän lisäksi Finnan alla on noin 50 kirjastojen ja 10 museoiden omaa näkymää, joiden kautta voidaan tarjota kansallisen Finna.fi:n aineistojen lisäksi esimerkiksi kirjautumista vaativia sähköisiä aineistoja, ryhmitellä aineistoja ja aineistonostoja tarkoituksenmukaisella tavalla sekä tuoda omien asiakkaiden käytettäväksi sellaisia palveluja kuin halutaan. Finnan kasvuvauhti on ollut nopeaa niin aineistojen kuin mukana olevien organisaatioiden määrän suhteen ja kasvu näyttää jatkuvan voimakkaana. Kirjastosektoreilla erityisesti yleisten kirjastojen mukaan tuleminen kasvattaa Finnan käyttömääriä huomattavalla tavalla.

\section{Avoin rajapinta api.finna.fi}

Osoitteessa api.finna.fi vastaa Finna.fin avoin rajapinta, jonka avulla muut järjestelmät voivat tehdä samoja hakuja Finnan indeksiin kuin mikä on mahdollista Finnan käyttöliittymän kautta. Avoimen rajapinnan myötä voidaan sanoa, että Finna tarjoaa ilman mitään lisävaivaa koneluettavan rajapinnan myös kaikille niille yli 200 organisaatiolle, jotka ovat tuoneet aineistonsa Finnaan. Jo nyt Finnan avointa rajapintaa käytetään useiden ulkoisten järjestelmien tiedonlähteenä ja tällaiset käyttötavat ovat voimakkaassa kasvussa. Aineistojen automaattinen käyttö tuo myös omat haasteensa, sillä luonnollisesti vaikkapa kuva-aineistoissa on puutteita esim. sijainti- ja ajoitustietojen suhteen. Indeksin tietoja pyritään rikastamaan automaattisin menetelmin, joissa esim. kuvausteksteissä olevien paikannimien ja osoitteiden perusteella määritellään kuville sijainteja, mutta harmillisesti tällainen prosessointi on altis myös tuottamaan virheellistä tietoa. Materi- aalin rikastamista voidaan lähestyä myös esimerkiksi tekoälytutkimuksen, kuvantunnistuksen ja kieliteknologian menetelmin sekä joukkoistamisen ja sosiaalisen validoinnin keinoin, mutta tässä ollaan vasta aivan alkutaipaleella.

\section{Finnan trendiraportti 2016}

Finnan vuotuinen trendiraportti on osa Finnan käyttäjälähtöistä kehitystyötä tukevaa toimintaa siinä missä säännöllisesti toteutettavat käytettävyys- ja esteettömyystestaukset tai työpajat käyttäjäryhmien kanssa. Trendiraportti on koostettu kerran vuodessa kaikissa Finna-näkymissä aukeavan käyttäjäkyselyn tuloksista sekä palvelun käyttöä mittaavan web-analytiikan esille tuomista tiedoista. On ollut erityisen ilahduttavaa, että käyttäjäkyselyyn osallistuminen on ollut varsin suosittua, sillä kyselyn tulokset ja erityisesti käyttäjien avovastaukset antavat aina tukun konkreettisia ajatuksia paitsi kansallisen Finna.fi-palvelun kehittämiseen, niin myös mukana oleville organisaatiolle nimenomaan organisaation oman Finna-näkymän muokkaamiseen yhä enemmän asiakkaita palvelevaan muotoon.

Korkeakoulukirjastot ovat pitäneet kärkeä Finnaan liittymisessä, ne ovat olleet ensimmäinen joukko suomalaisista kirjastoista, arkistoista ja museoista, jotka lähes kokonaisuudessaan ovat liittyneet Finnaan ja toteuttaneet verkkokirjastonsa Finnan päälle. Opiskelijat myös käyttävät oman organisaationsa verkkokirjastoja aktiivisesti. Tämä näkyy Finnan käyttäjäkyselyn vastaajissa. Aiempina vuosina suurin joukko vastaajista on ollut opiskelijoita ja tänäkin vuonna opiskelijat olivat suurin vastaajaryhmä (69\%).

Sähköinen kysely on kvantitatiivinen menetelmä ja se soveltuu keräämään yksiselitteisiä vastauksia selkeisiin kysymyksiin, mutta sen kautta on vaikea saada laadullista syvällisempää ymmärrystä käytöstä ja käyttäjien tarpeista. Kyselyn kautta voidaan muodostaa yleisarvosanoja tietyille osa-alueille sekä vertailla onko käyttäjäryhmien välillä merkittäviä eroja johonkin suuntaan tyytyväisyydessä. Kyselyllä voidaan seurata 
yleistä yleisarvosanojen kehitystä ja mahdollisesti identifioida osa-alueita joita tutkia kvalitatiivisin menetelmin lisää.

\section{Yleisarvosana Finnalle hyvä}

Finna sai yleisarvosanaksi 8 (asteikolla 0-10) kuten kahtena aiempanakin vuonna. Net Promotor Score eli kysymyksen: "Kuinka todennäköisesti suosittelisit Finnaa muille? (asteikolla 0-10)" perusteella muodostettu arvio oli +30 . Karkeasti Net Promotor Score kertoo prosentuaalisen osuuden kuinka paljon enemmän suosittelijoita oli enemmän kuin arvostelijoita. +30 tarkoittaa sitä, että suosittelijoita oli merkittävästi enemmän, vaikka ei ole yksiselitteistä asteikkoa sille mikä on hyvä ja huono NP-arvo, vaan merkittävämpää on, miten arvo kehittyy mittausajankohtien välillä. Edeltävänä vuonna asteikko ja kysymyksenasettelu olivat erilaisia, joten kehityksen trendiä ei vielä tänä vuonna voi nähdä. Yleinen löydettävyys (kysymys: "Löysitkö etsimäsi?") on kasvanut pikkuhiljaa vuosi vuodelta ja oli tänä vuonna jo $86,3 \%$. Ainoastaan 4,7 \% ei löytänyt etsimäänsä, loppujen ollessa henkilöitä, jotka eivät etsineet mitään tiettyä. Käyttäjistä $63 \%$ kertoi myös löytäneensä muutakin kiinnostavaa Finnan kautta.

\section{Opiskelijat, tutkijat ja korkeakouluopettajat}

Opiskelijat, tutkijat ja korkeakouluopettajat ovat kiinnostavimmat käyttäjäryhmät tieteellisten kirjastojen näkökulmasta. He tulevat Finnaan pääasiassa etsimään tiettyä aineistoa tai kiinnostavaan aiheeseen liittyvää tietoa sekä hallinnoimaan varauksiaan tai aineistojensa lainoja. Kuten rooleista voi olettaa, ryhmät etsivät tietoa opiskeluun, akateemiseen tutkimukseen ja opetukseen. Tutkijat löysivät ehkä hivenen harvemmin etsimänsä (83 \%) kuin Finnan keskiarvokäyttäjä (86 \%), mutta heidän hakunsa kohdistuikin hyvin erityisiin aiheisiin ja he mainitsivat saattavansa etsiä niin uutta materiaalia, että se ei vielä ollut saatavilla. Opiskelijat taas melkein kaikki (90 \% vastaajista) löysivät etsimänsä. Opiskelijoiden ja korkeakouluopettajien Net Promoter Score -arvo oli +29 , mikä oli hyvin vastaava kuin Finnan keskimääräinen arvo +30 . Tutkijat taas olivat hivenen kriittisempiä arvolla +23 .

Opiskelijat, korkeakouluopettajat ja tutkijat olivat selvästi kiinnostuneempia elektronisista aineistoista kuin kaikki Finnan käyttäjät yhteensä. Ainoastaan kirja-aineistoissa perinteinen paperiversio kiinnosti lähes yhtä paljon kuin e-kirja, mutta opettajat ja tutkijat käyttivät mieluummin verkossa saatavilla olevia. Muun tyyppisissä aineistoissa (lehdet ja artikkelit, kuvat, videot ja äänitteet, opinnäytteet, kartat, nuotit, taideteokset, arkistoaineistot sekä yllättäen esineet) opiskelijoiden, korkeakouluopettajien ja tutkijoiden preferenssi oli erittäin selkeästi verkossa saatavilla olevissa aineistoissa.

Yleisarvosanojen mittaus näyttää vuosittaisen yleisen kehityksen suunnan, mutta palvelun kehittäjille ja toteuttajille kyselyn vapaatekstivastaukset ovat kaikista hyödyllisin osa. On varsin työlästä käydä lävitse ja analysoida tuhansia vapaatekstivastauksia manuaalisesti ja teemmekin sen käyttäjäryhmä kerrallaan vähitellen. NPS-arvosanan perusteella tutkijat olivat tieteellisten kirjastojen käyttäjäryhmistä kriittisin ryhmä (vain hivenen, mutta kuitenkin). Kyselyyn vastanneista oli tutkijoita n. 500 ja heidän vapaatekstivastauksistaan voidaan löytää muutama isompi teema. Suurin esiin noussut teema oli, että tutkijat toivoivat yleisesti parannusta käytettävyyteen eli yksinkertaisempaa ja konsistentimpaa käyttöliittymää. Erityisesti artikkelihaun ja elektronisten aineistojen haun yksinkertaistamista ja parantamista toivottiin. Kommenttien perusteella vaikuttaa siltä, että ylipäätään polkua artikkeli- ja e-aineistohakuihin tulisi kehittää: hakujen targetointi oli vaikeaa tai epäselvää, ja pääsy hakutuloksista itse artikkeleita lukemaan vaikutti vaikealta. Yleisesti toivottiin parempia hakutyökaluja. Hakutuloksiin myös kaivattiin selkeämmin esiin saatavuus- ja käyttöoikeustietoja. Tutkijat toivoivat myös, et- 
tä kirjautuminen palveluun tuotaisiin suoraviivaisemmaksi ja voimakkaammin esiin sen etusivulla. Kaikkien ryhmien palautteesta nousee selkeä toive saada lisää aineistoja sekä oman organisaationsa kirjastoon että vapaasti verkkoon: lisää e-kirjoja, lisää artikkelitietokantoja, lisää karttoja, lisää vapaasti käytettäviä kuvia, lisää kuvia esineistä jne.

\section{Seuraava askel - laadullinen käyttäjälähtöinen tutkimus}

Käyttäjäkysely ja verkkoanalytiikka antavat tietoa vain tiettyyn pisteeseen saakka. Ne ovat kvantitatiivisia menetelmiä, jotka palvelu- ja käyttöliittymäkehityksen näkökulmasta tarvitsevat tuekseen laadullisen tutkimuksen menetelmiä. Käyttäjäkyselyn ja verkkoanalytiikan voidaan ajatella olevan ensimmäinen sytyke idealle siitä, mitä lähteä parantamaan käyttöliittymässä. Niistä kuitenkin harvemmin vielä saadaan irti, kuinka käyttöliittymää tarkalleen ottaen tulisi parantaa. Ideaalitilanteessa seuraava askel olisi tehdä laadullista syväluotaavampaa tutkimusta loppukäyttäjien parissa esim. haastattelemalla, työpajoissa tai käytettävyystestauksella pienemmällä otoksella syvemmän ymmärryksen muodostamiseksi. Tämän syventävän tiedon perusteella olisi jo mahdollista luoda tarkempi vaatimusmäärittely ja lähteä ideoimaan konkreettista ratkaisua. Edelleen kun konkreettinen konsepti esim. paperiprototyyppitasolla olisi olemassa, käyttäjät tulisi ottaa mukaan arvioimaan ideana toimivuutta esim. työpajan tai käytettävyystestauksen muodossa.

\section{Käyttäjäkeskeinen suunnittelu Finnassa}

Finnassa on projektin alusta lähtien pyritty käyttäjälähtöiseen suunnitteluun. Käyttöliittymävaatimuksia on mietitty loppukäyttäjän kannalta, teetetty säännöllisesti käytettävyystestejä tuotannossa olevalle järjestelmälle ja käyttäjätutkimustakin on tehty. Seuraava tavoite Finnassa on saada käyttäjien osallistaminen kaikkiin isompiin konseptointi- ja käyttöliittymäparannusprojekteihin arkipäiväksi jo konseptointivaiheessa. Kun isompia asioita lähdetään ideoimaan, on tarkoitus, että loppukäyttäjien kanssa saadaan järjestettyä esim. työpaja, ja kun konseptointi on edennyt luonnosten ja prototyyppien tasolle, on tarkoitus järjestää pienimuotoista käytettävyystestausta osana kehitysprosessia ja pyrkiä löytämään pahimmat ongelmat saman tien. Tämän tavoitteen saavuttamiseksi Finna tulee tarvitsemaan tukea osallistuvilta kirjastoilta, arkistoilta ja museoilta, sillä he ovat rajapinta lopullisiin käyttäjiin.

Trendiraportti Finna - Käyttö ja trendit 2016 on löydettävissä Finnan asiakaswikistä osion Opinnäytteet ja tutkimukset alta: https://www.kiwi.fi/x/3wkXAw

\section{Tietoa kirjoittajista:}

Jyrki Messo, tietojärjestelmäasiantuntija
Helsingin yliopiston kirjasto
Jyrki.messo@helsinki.fi
Riitta Peltonen, johtava käytettävyyssuunnittelija
Helsingin yliopiston kirjasto
Riitta.peltonen@helsinki.fi

